Pesq. Vet. Bras. 30(9):783-786, setembro 2010

\title{
Nuclear and mitochondrial DNA markers in traceability of retail beef samples ${ }^{1}$
}

\author{
Aline S.M. Cesar², Fernando H. Biase ${ }^{2}$, Paula Ripamonte ${ }^{2}$, Albino Luchiari \\ Filho $^{3}$, Giovana K. Merighe ${ }^{2}$ and Flávio V. Meirelles ${ }^{2^{*}}$
}

\begin{abstract}
Cesar A.S.M., Biase F.H., Ripamonte P., Luchiari Filho A., Merighe G.K. \& Meirelles F.V. 2010. Nuclear and mitochondrial DNA markers in traceability of retail beef samples. Pesquisa Veterinária Brasileira 30(9):783-786. Laboratório de Morfofisiologia Molecular e Desenvolvimento, Faculdade de Zootecnia e Engenharia de Alimentos, Universidade de São Paulo, Av. Duque de Caxias Norte 225, Pirassununga, SP 13635-900, Brazil. E-mail: meirellf@usp.br

Several characteristics are important in a traceability system of animal products, such as age at slaughter, breed composition, besides information of the productive chain. In general, the certification agent records information about the animals and the system which it came from, although cannot guarantee that the slaughtering, meat processing and distribution are error proof. Besides, there is a differential price, at least at the international market, based on sex and breed composition of the animals. Genetic markers allow identification of characteristics controlled in the beef cattle traceability program, as sex and breed composition, in order to correctly identify and appraise the final product for the consumer. The hypothesis of this study was that the majority beef samples retailed in the local market originate from female with a great participation of zebu breeds. Therefore, the objective of this work was to characterize retail beef samples with DNA markers that identify cattle sex and breed composition. Within 10 beef shops localized in Pirassununga, SP, Brazil, 61 samples were collected, all were genotyped as harboring Bos taurus mitochondrial DNA and 18 were positive for the $Y$ chromosome amplification (male). For the marker sat1711b-Msp I the frequency of the allele $A$ was 0.278 and for the marker Lhr-Hha I the frequency of the allele T was 0.417. The results of sat $1711 \mathrm{~b}-\mathrm{Msp}$ I and Lhr-Hha I allelic frequencies are suggestive that the proportion of indicus genome compared with the taurine genome in the market meat is smaller than the observed in the Nellore breed. The procedure described in this study identified sex and subspecies characteristics of beef meat samples, with potential application in meat products certification in special as an auxiliary tool in beef cattle traceability programs.
\end{abstract}

INDEX TERMS: Bos indicus, beef, stDNA, mtDNA, traceability.

RESUMO.- [Marcadores de DNA nuclear e mitocondrial para rastreabilidade da carne bovina comercializada.] Várias características são importantes no sistema de rastreabilidade, como o sexo, a idade, a raça e/ou a composição racial dos animais, além de dados da cadeia produtiva. Em

\footnotetext{
${ }^{1}$ Received on April 7, 2010.

Accepted for publication on July 15, 2010.

2 Departamento de Ciências Básicas, Faculdade de Zootecnia e Engenharia de Alimentos (FZEA), Universidade de São Paulo (USP), Pirassununga, SP 13635-000, Brazil. " Corresponding author: $\underline{\text { meirellf@usp.br }}$

${ }^{3}$ Departamento de Zootecnia, Escola Superior de Agricultura "Luiz de Queiroz" (ESALQ), Universidade de São Paulo (USP), Piracicaba, SP 13418-900, Brazil
}

geral, a empresa certificadora dispõe das informações do animal que está sendo abatido, porém não tem condições de garantir se houve erro entre abate, desossa, processamento e a distribuição dos produtos. Existe diferenciação no custo e na qualidade dos produtos cárneos, especialmente no mercado internacional, em virtude do sexo e composição racial dos animais. Os marcadores genéticos permitem identificar as características que são controladas num programa de rastreabilidade bovina tais como sexo e composição racial, permitindo identificar e avaliar corretamente para o consumidor, o produto final. A hipótese deste estudo foi que a maioria das amostras de carne bovina vendida no mercado local seria proveniente de fêmeas e com grande participação de raças Zebu. O objetivo deste trabalho foi caracterizar amostras de 
carne bovina com marcadores de DNA para identificar o sexo e a composição racial. Em dez pontos comerciais da cidade de Pirasssununga, SP, Brasil, foram coletadas 61 amostras e todas foram genotipadas como possuindo DNA mitocondrial Bos taurus e 18 foram positivos para amplificação do cromossomo $Y$ (macho). Para o marcador sat1711b-Msp I a frequência alélica do A foi 0.278 e para o marcador Lhr-Hha I a frequência alélica do $T$ foi 0.417 . Os resultados das frequências alélicas do sat1711b-Msp I e Lhr-Hha I apresentaram menor proporção do genoma Bos indicus em relação ao Bos taurus quando comparado ao rebanho Nelore. Com a metodologia descrita neste trabalho foi possível avaliar o sexo e as características de subespécie das amostras de carne bovina, tendo uma importante aplicação para a certificação de produtos cárneos especialmente, em programas de rastreabilidade animal.

TERMOS DE INDEXAÇÃO: Bos indicus, carne bovina, stDNA, mtDNA, rastreabilidade.

\section{INTRODUCTION}

After the spreading of foot and mouth disease, BSE and other sanitary problems around the world, the European Community countries, as well as countries from other regions started a demand for traceability of animal origin products (Daqq et al. 2005). Traceability means the capability of tracing back and forward with confidence all the steps of a product and its production process (Victorelli Neto 2004).

Brazil has the second largest beef herd in the world (FAO 2007), with its increasing levels of efficiency and productivity therefore keeping high standards is vital to the beef cattle industry. In this scenario, traceability is an important tool for beef chain in order to maintain and to open new beef markets.

In the traceability system, several characteristics are controlled as, sex, subspecies and the degree of crossbreeding of the animals, especially when zebu cattle (Bos indicus) is part of the crossbreeding scheme (Comunidades Européias 2000). Although consistent procedures are applied on a traceability program, no system can be fail proof unless checking procedures can be performed.

The cattle can be divided in two main groups: the European (B. taurus) and the Indian zebu cattle (B. indicus). Although the classical division by Lineu considers these groups as separate species, several authors have stated that they are subspecies (Manwell \& Baker 1980).

Cattle $B$. taurus breeds such as Angus and Hereford now became synonymous of the most appreciated and tasty flesh of the world (Luchiari \& Mourão 2006), highly priced in the international market. The Japanese market, for example, prefers beef with a high percentage of intramuscular fat. It can reach 20 to $30 \%$ of fat in the superior quality of beef type (Jurie et al. 2007), with a typical characteristic of these breeds. Thus, animals that have in their composition $B$. taurus breeds can reach the higher prices market. Increased demand for these products is seen in the Asian markets for beef.

Molecular markers have been used for a precise identification in between these groups, the European (B. taurus) and the
Indian zebu cattle (B. indicus). According to Loftus et al. (1994) DNA polymorphism sequence of mitochondrial ( $m t D N A)$ was identified in D-loop region, as well as in less variable regions as transporter RNAs (Pegoraro et al.1995) and 16S (Meirelles et al. 1999). A mendelian inherited variation was also described in the centromeric satellite region of the nucleic DNA which introduces a restriction site in part of the $B$. indicus animals (Nijman et al. 1999; Ripamonte 2002). These sequences usually localized at the chromosomes heterochromatin are close to the centromers (Charlesworth et al. 1994).

Analyzing the $1711 \mathrm{~b}$ DNA satellite of $B$. taurus, $B$. indicus and its hybrids, it was observed that species closely related can show variable sequences of these satellites, which can be used as marker in crossbreed studies of zebu with european cattle breeds. Actually, several markers are polymorphic recognized between $B$. taurus and $B$. indicus animals. The gene of the luteinizing hormone receptor (LHR) contains these polymorphisms. A punctual mutation in the 1328 position which carries to a base change, cytosine (C) for thymidine (T) was described in Nellore breed (Milazzotto 2007). Zebu cattle specifically harbor the T allele ( 0.755 for allele $T$ versus 0.245 for allele $C$ ), instead of European animals that harbors $\mathrm{C}$ allele exclusively. The recent report of the bovine genome assembly (Elsik et al. 2009), as well as the study identifying variability among cattle from different breeds will provide new features about the cattle genome that will certainly be useful for traceability programs. The hypothesis of this study was that the majority beef samples retailed in the local market originate from female with a great participation of zebu breeds.

Based on these evidences, the objective of this study was to characterize beef samples with DNA markers to identify the gender and racial composition.

\section{MATERIALS AND METHODS}

Beef samples $(n=61)$ were collected in ten different selling points in Pirassununga, SP, Brazil, along the months of April and May of 2005 and DNA from all samples was extracted by salt precipitation (Biase et al. 2002). All samples were informed to be male derived. Briefly, about $0,2 \mathrm{~g}$ of muscle were weighed, pondered with liquid nitrogen and dissolved in $800 \mu \mathrm{L}$ of lyses buffer and $4 \mu \mathrm{L}$ of protein $\mathrm{k}$ solution $(50 \mathrm{mg} / \mu \mathrm{L})$. The cell lysate solution was heated $55^{\circ} \mathrm{C}$ for $5 \mathrm{~h}$. After addition of $300 \mu \mathrm{L}$ of salt saturated solution ( $\mathrm{NaCl} 5 \mathrm{M})$, we proceeded centrifugation at $21.000 \mathrm{xg}$ for 15 minutes. The supernatant was collected in a new tube and $1.2 \mathrm{~mL}$ of ethanol $100 \%$ was added to induce DNA precipitation. The pellet was eluted in $50 \mu \mathrm{L}$ of DNase free water. DNA amount was estimated by spectrophotometry at $260 / 280 \mathrm{~nm}$ absorbance and quality observed in agarose gel $(0.8 \%)$ electrophoresis stained with ethidium bromide. Primers and restriction enzyme used in this article are listed in Table 1. The SRY marker identifies the male sample origin by the presence or not of the $\mathrm{Y}$ chromosome amplified fragment. This reaction was run in a multiplex with a satellite region (Ellis \& Harpold 1986; Ellis \& Harpold 1988) common to both sex genomes. The reaction was set with $120 \mathrm{ng}$ of DNA, enzyme buffer (1x), $\mathrm{MgCl}_{2}(50 \mathrm{mM})$, dNTP (100 $\mu \mathrm{M}$ each), $10 \mathrm{pmol}$ of each primer pair and Taq DNA polymerase (1U) in a final volume of $25 \mu \mathrm{l}$. Thermocycler program was $95^{\circ} \mathrm{C}, 2$ 
Table 1. Primers and restriction enzyme used for each polymorphic loci

\begin{tabular}{ccc}
\hline Marker & Primers 5' $\rightarrow$ 3' & $\begin{array}{c}\text { Restriction } \\
\text { enzyme }\end{array}$ \\
\hline mtDNA & F - CCC AAC GAG GAA AAT ATA CC & Hind III \\
& R - AAC CGC AAA CAA CCT CTT CC & \\
Sat1711b & F- CCC ACT ACC TCT CTC TGA AAA & Msp I \\
& R - TGA TCC AGG GTA TTC GAA GGA & \\
Lhr & F - CAA ACT GAC AGT CCC CCG CTT T & Hha I \\
& R - CTC CGA GCA TGA CTG GAA TGG C &
\end{tabular}

minutes; $35 \times\left(94^{\circ} \mathrm{C}, 25\right.$ seconds; $62^{\circ} \mathrm{C}, 20$ seconds; $72^{\circ} \mathrm{C}, 45$ seconds) and a final heat of $72^{\circ} \mathrm{C}, 10$ minutes. The LHR and sat1711a were amplified in order to identify the presence of nuclear specific $B$. taurus and $B$ indicus alleles, respectively. Hence, in order to identify the matrilineal ancestrally a mitochondrial SNP (mtDNA) was also evaluated. The reactions were carried individually and the reaction conditions were as described above, except for the annealing temperature: $58^{\circ} \mathrm{C}$, $62^{\circ} \mathrm{C}$ and $58^{\circ} \mathrm{C}$ for LHR, sat1711a and mtDNA primers, respectively. Reactions products for LHR, sat1711a and mtDNA (15 $\mathrm{ll})$ were directly subjected to enzymatic restriction (Hha I, Msp I and Hind III, respectively). The final products of PCR or PCR-RFLP were submitted to electrophoresis in $2 \%$ agarose gel with ethidium bromide. The images were captured in a laser scanner FujiFilm3000.

Genotypic and allelic frequencies were calculated for the entire sample and separately for male and female samples (Weir \& Cockerham 1984). The allelic frequencies were compared between male and female using Fisher exact test in contingency table (Raymont \& Rousset 1995) and the probability of genotypic disequilibrium between each polymorphic markers were estimated in the sample and within male and female samples (Guo \& Thompson 1992). Comparisons between the allelic data observed herein and the previously reported was performed using contingence table applying Fisher's method (Raymont \& Rousset 1995). Estimates were calculated using the GENEPOP software (Raymont \& Rousset 1995) and a result was considered statistically significant when $p<0.05$.

\section{RESULTS AND DISCUSSION}

Amplification of the four markers was possible for all samples. The observed PCR or PCR-RFLP bands profiles are depicted in Figure 1.

Of the 61 collected samples, $39(64 \%)$ were positive for the $\mathrm{Y}$ chromosome amplification (male) and only 27 were

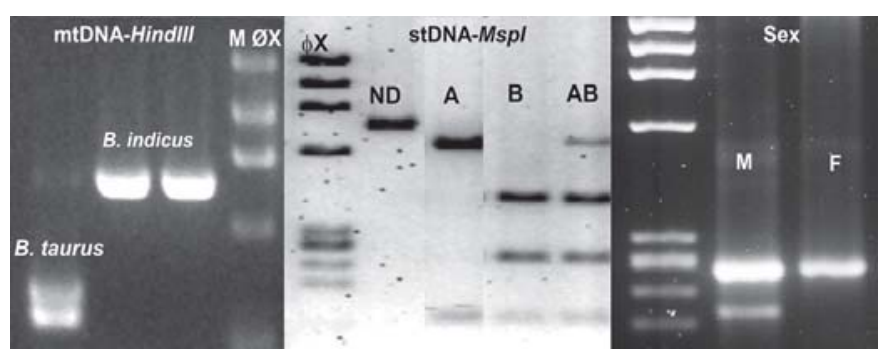

Fig.1. Electrophoresis on agarose gel $2 \%$ representing PCRRFLP of mtDNA - Hind III, stDNA - Msp I, and sexing markers respectively.
Table 2. Genotypic frequencies for mitochondrial DNA (mtDNA-Hind III) and gene frequencies for satellite 1711bMsp I and LHR-Hha I polymorphisms

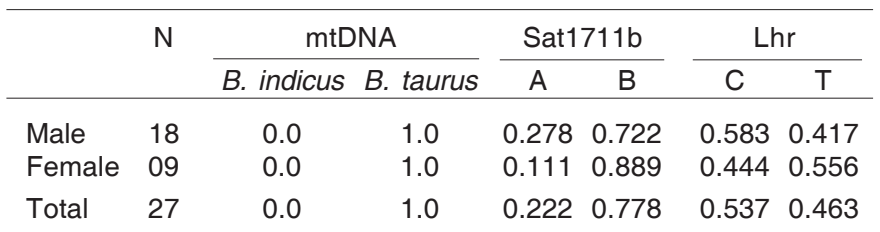

genotyped as harboring $B$. taurus mitochondrial DNA and used in this experiment. The allelic frequencies of the LHR and sat $1711 \mathrm{~b}$ markers for total sample and within the sexes are presented in (Table 2). Using the satellite marker, one individual was genotyped as AA ( $B$. indicus specific allele) and 10 were heterozygous. The LHR marker evaluation showed most of the individuals with heterozygous genotype $(n=15)$ and 07 animals were genotyped as homozygous for the $B$. taurus specific allele (C). Both LH and sat $1711 \mathrm{~b}$ alleles were in HardyWeinberg equilibrium and there was no genotypic disequilibrium between the sat $1711 \mathrm{~b}$ and LHR loci.

Most of the Brazilian heard is comprised of Nellore breed or Nellore crossbred animals. Despite the limited sample number, our results compare with Nellore data and observed that the mitochondrial DNA genotype and nuclear allelic frequencies observed herein are not in accordance with previous findings observed for Nellore sample $(p<0.05)$. Meirelles et al. (1999) reported the presence of indicus mtDNA in $43.4 \%$ of the purebreed Nellore sample examined. This data however may over estimate $B$. indicus mtDNA contribution to the Nellore population since it included closed herds with descendent exclusive from imported animals. Overall data from Nellore sample $(n=367)$ genotyped in our laboratory indicate that $16.34 \%$ have $B$. indicus matrilineal origin (Ripamonte 2002). Regarding the satellite polymorphism, the A allele frequency in the laboratory dataset (Nellore, $\mathrm{n}=311$ ) was 0.4068 (Ripamonte 2002). Milazzoto (2007) reported LHR-Hha I allelic estimation for Nellore breed and the $\mathrm{C}$ allele frequency was 0.245 .

Nellore is the zebu breed most abundant in the Brazilian heard, however the results of sat1711b-Msp I and LHR$H$ hal allelic frequencies are suggestive that the proportion of indicus genome compared with the taurine genome in the market meat is smaller than the observed in the Nellore purebred herd. The taurine matrilineal origin of the slaughtered animals, when compared with data of purebred animals reported previously by Ripamonte (2002) is in accordance with this observation. Further analysis increasing the number of markers and animals genotyped will be helpful to estimate the genomic composition of the meat, allowing the estimation of subspecies contribution at individually and therefore providing parameters that can help the establishment of traceability programs.

\section{CONCLUSIONS}

Based on these results we conclude that beef marketed in Pirassununga-SP are predominantly from males with the 


\section{Bos indicus specific alleles frequency representatively lower compared to Nellore cattle. \\ With the procedure described it was possible to evaluate sex and subspecies contribution to meat samples. These methodologies have potential application in meat products certification in special as an auxiliary tool in beef cattle traceability programs.}

Acknowledgements.- To FAPESP and CNPq for the financial support.

\section{REFERENCES}

Biase F.H., Franco M.M., Goulart L.R. \& Antunes R.C. 2002. Protocol for extraction of genomic DNA from swine tissues. Genet. Mol. Biol. 25:313-315.

Charlesworth B., Snlegowski P. \& Stepphan W. 1994. The evolutionary dynamics of repetitive DNA in eukaryotes. Nature 371:215-220.

Comunidades Européias 2000. Regulamento (CE) no 1760/2000 do Parlamento Europeu e do Conselho, de 17 de Julho de 2000. Jornal Oficial das Comunidades Européias, 11 de Agosto de 2000, 204:1-9.

Ellis S.B. \& Harpold M.M.1986. Nucleic acid probes for prenatal sexing. International application published under the Patent. Cooperative Treaty (PCT) World Intellectual Property Organization. Publication no. WO 86/07095.

Ellis S.B. \& Harpold M.M. 1988. Nucleic acid probes for prenatal sexing. U.S. Patent no. 4.769.319.

Elsik C.G., Ross L., Tellam R.L. \& Worley K.C. 2009. The Bovine Genome Sequencing and Analysis Consortium. The genome sequence of taurine cattle: A window to ruminant biology and evolution. Science 324:522-528.

FAO 2007. Food and Agriculture Organization of the United Nations. Available at <http://faostat.fao.org/site/612/default.aspx\#ancor> Accessed 10 Jun. 2009.

Guo S.W. \& Thompson E.A. 1992. Performing the exact test of HardyWeinberg proportion for multiple alleles. Biometrics 48:361-372.

Jurie C., Cassar-Malek I., Bonnet M., Leroux C., Bauchart D., Boulesteix P., Pethick D.W. \& Hocquette J.F. 2007. Adipocyte fatty acid- binding protein and mitochondrial enzyme activities in muscles as relevant indicators of marbling in cattle. J. Anim. Sci. 85:2660-2669.

Loftus R.T., Machugh D.E., Ngere L.O., Balain D.S., Badi A.M., Bradley D.G. \& Cunningham E.P. 1994. Mitochondrial genetic variation in European, African, and Indian cattle populations. Anim. Genet. 25:265-271.

Luchiari Filho A. \& Mourão G.B. 2006. Melhoramento, Raças e seus Cruzamentos na Pecuária de Corte Brasileira. Editora A. Luchiari Filho, São Paulo. 14p.

Manwell C. \& Baker C.M.A. 1980. Chemical classification of cattle. 2. Phylogenetic tree and specific status of the Zebu. Anim. Genet. 11:151162.

Meirelles F.V., Rosa A.J.M., Lobo R.B. \& Garcia J.M. 1999. Is the American zebu really Bos indicus? Genet. Mol. Biol. 22:543-546.

Milazzotto M.P., Feitosa W.B., Strauss B.E., Bajgelman M., Mendes C.M., Assumpção M.E.O.D. \& Visintin J.A. 2007. Myostatin gene knockdown through lentiviral vector-mediated delivery of shRNA for in vitro production of transgenic bovine embryos. International Embryo Transfer Society, Kyoto. Reprod. Fertil Dev. 19:120-120.

Nijman I.J., Bradley D.G., Hanotte O., Otsen M. \& Lenstra J.A. 1999. Satellite DNA polymorphisms and AFLP correlate with Bos indicustaurus hybridization. Anim. Genet. 30:265-273.

Pegoraro L., Yang Z., Samaké S., Meirelles F.V., Bordingnon V., Moquin L.C. \& Smith L.C. 1996. Sequence comparison of mitochondrial tRNA genes and origin of light strand replication in Bos taurus and Nellore (Bos indicus) breeds. Anim. Genet. 27:91-94.

Raymond M. \& Rousset F. 1995. GENEPOP (version 1.2): population genetics software for exact tests and ecomenicism. J. Heredity 86:248249.

Ripamonte P. 2002. Estimativa da participação do genoma de Bos taurus no rebanho nelore. Dissertação de Mestrado, Faculdade de Zootecnia e Engenharia de Alimentos, Universidade de São Paulo, Pirassununga. 57p.

Victorelli Neto H. 2004. Rastreabilidade e certificação, a nova realidade da pecuária. ANUALPEC: Anuário da Pecuária Brasileira, São Paulo, p.53-54.

Weir B.S. 1996. Genetic data analysis: Methods for discrete population genetic data. $2^{\text {nd }}$ ed. Sinauer Associates, Massachusetts. 